\title{
A STUDY OF THE EMERGENCE AND GROWTH OF INDIAN SHORT FICTION IN ENGLISH
}

\author{
SHAKUNTALA AGARWAL
}

Keshav Memorial Institute of Technology, Telangana, India

\begin{abstract}
The present paper aims to trace the emergence and the growth of Indian short fiction in English from its inception to the present. The purpose of this paper is to present, in a nutshell, the birth of the short story as a literary genre in the $19^{\text {th }}$ century. The techniques and devices used by the writers. The three phases through it passed. The themes and the prominent short story writers in English.
\end{abstract}

KEYWORDS: Emergence, Growth, Techniques\& Short-Fiction

Received: Aug 08, 2020; Accepted: Aug 28, 2020; Published: Oct 10, 2020; Paper Id.: IJELAUG20209

\section{INTRODUCTION}

Storytelling is an ancient art form, hailing from time immemorial. People have amused themselves over the centuries narrating imaginary events in the form of legends, fables, myths, anecdotes, and adventures. This tradition of oral narration gradually developed into prose fiction and gave birth to the modern short story. This was given proper shape and form in the $19^{\text {th }}$ century. It took a considerable time to reach its proper excellence.

India, with its unique culture of literary heritage, is home to stories. Our love for storytelling is reflected in the 'Panchatantra', 'Jataka Mala', 'Kadambari', and many more. 'The Kathasaritsagara' written in the $11^{\text {th }}$ century is the largest collection of stories in the world. These depict with kaleidoscopic colours and patterns of the soil and colour of India.

Mulk Raj Anand rightly acknowledges, "Only by going back to the forms of these stories told by mother to son could we evolve a new pattern for the contemporary short story. The modern short story is a highly developed folk tale" [1]. R.K Narayan also voices the same, he says "for any short story writer, the prototype remains to be our epics and mythological characters" [2].

A similar collection of tales and fables can be traced in other parts of the world as early as $4^{\text {th }}$ century B.C., 'The Tales of Magicians', 'The Arabian Night Tales', 'The Iliad', 'The Odyssey', and 'The Canterbury Tales' of Chaucer have indirectly contributed to the development of modern short stories.

However, ancient fiction was quite different from the fiction of today. The language was artificial, ornamental and the tone was didactic. They were removed far from reality. They were untrue accounts of magic, gods, demons, strange quests impossible, tasks, and miraculous transformations.

The short story as a literary genre appeared and received attention in the $19^{\text {th }}$ century. The quest for new forms of social life actively pushed this to the forefront. In an age, where readers could not spend more than an hour or two for works of fiction, this new form had wide appeal. New devices and new techniques were used. An 
art which had remained neglected suddenly received worldwide recognition.

Creative writers found in it a new and exciting medium of expression, a convenient mode to express their newly awakened literary consciousness. They raised it to the level of art, deliberate and scientific in conveying the truth.

Macaulay's scheme of education and the synthesis of the eastern and western heritage had a strong impact on Indian writers in English. The growth was given a further impetus with the growth of periodical literature. Writers were pressed to contribute stories for the newly launched journals. We can say that the foundation of this genre was laid on the pages of these journals.

"In the $19^{\text {th }}$ century in the field of literature, we find four great short story writers. Guy-de-Maupassant, Anton Chekov, Edgar Allen Poe, and Rabindranath Tagore. All of them started writing for the same reason, namely to fulfill the demands of different journals" states N. Ganopadhaya [3].

The journals thus brought about an increased interest among the masses in the short story. Through this platform, the creative writers reached to the people. Without these journals, the short story could not have been what it is today.

The Indian fiction in English since its birth has passed through three phases. The first one as we have seen is the ephemeral phase of the historical stories. The second is the long-lived phase of socio-political stories marked by realism. The third is the phase of the psychological short story with a concern for the private and the inner world of the protagonists.

Any episode or an event can be the subject matter for a short story. It provides the plot which is developed through a few characters and dialogues. It may be based on suspense, surprise, human values, empathy, or the darker moments of life. But by and large, it maintains the common factors required for a novel or a drama. Its aim is not only to delight and instruct but also to make one feel and think. It can console the readers, amuse them, make them sad, sympathetic, dream, laugh, and shudder. It acts as an antidote to care and boredom. It calls for brevity, unity, cohesion, and swift movement.

The most dominant themes used by the Indian writers in English are the burning problems of contemporary life and the individual's quest for identity. Stories about social evils like Sati, child marriages, superstitions, oppression of the poor and the marginalized, and the natural calamities, the national movement, the impact of Gandhiji and his philosophy, Partition and its aftermath, the-holocaust of the two World Wars, The Independence, the merging of the princely states with the Indian Union, wars with China and Pakistan, Impact of the west, development of science and technology, the industrial growth, urbanization, political and social upheavals, corruption, violence, professional commitment, westernization, motherhood, parenting, sexual harassment, and search for identity are issues used as themes used by the well-known Indian writers in English short story.

India has a long list of writers in English. Earliest among these are R.S. Hossein, Cornellia, Sorabji, Rabindranath Tagore, Sarojini Naidu, Raja Rao, Mulk Raj Anand, R.K. Narayan, K. A. Abbas, Manohar Malgaonkar, G.V. Dasani, Mrinalini Sarabhai, Khushwant Singh, Ruskin Bond, Salman Rushdie, Niradh Chowdhary, Kamala Markandaya, Jumpa Lahari, and Ruth Jhabvala.

Many modern writers who have also contributed to this form are Arun Joshi, Amitav Gosh, Amitatv Chatterjee, Vikram Seth, Anita Desai, Nayantara Sahgal, Sashi Deshpande, Kamala Das, Geetha Mehta, Bharati Mukherjee, Padmini 
Sen, Chaman Nehal, Firdaus Kanga, Veena Nagpal, Chetan Bhagat, Devdutt Pattanaik, Ashwin Sanghi and many more.

\section{CONCLUSIONS}

To sum up, the literary output of Indian short fiction spans over more than a century. The Indian fiction writers in English have produced short fiction that stands out as a landmark in the history of Indian literature in English. These stories are small in size, like precious jewels, but rich in value.

\section{REFERENCES}

1. Anand, M. K. (1955). "Preface to Indian fairy tales", 4-5.

2. Neelima, Chennaiahgari. "The Place of Nostalgia in Diaspora Writing: Home and Belonging in The Fiction Of Bharati Mukherjee." International Journal of English and Literature (IJEL) 4 (2014): 33-40.

3. Narayan, R. K. (1970). "Views of Indian Novelists”, Indian and foreign review, 17(15), 12.

4. Oberoi, Sonia Vashishta. "Indian Chick Lit: A Genre For Desi Girls." International Journal of English and Literature (IJEL) 7.2 (2017): 127-132.

5. Dar, Bilquees. "The Theme of Partition in Khushwant Singh's Novel Train to Pakistan." International Journal of English Language and Linguistic Research 1 (2013): 21-23.

6. Devi, K. Lakshmi. "Figurative Language and Imagery in the Short Stories of John Updike." International Journal of Linguistics and Literature (IJLL) 5.4, Jun - Jul 2016; 49-52

7. Gangopadhyay. N. (1961). "The short stories of Rabindranath”, Rabindranath, Calcutta. 
